\title{
Volatility Spillovers from The International Capital Inflows to Economic Growth in Turkey
}

\author{
Arif Orçun Söylemez ${ }^{\bowtie}$ \\ Department of Economics, Marmara University, Turkey
}

\section{Info Articles}

History Articles:

Received 1 December 2016

Accepted 15 January 2017

Published 2 February 2017

\section{Keywords:}

economic growth

international capital;

GARCH model; volatility

spillovers; volatility

\begin{abstract}
This paper empirically investigates the volatility interactions between the international capital inflows to Turkey and Turkish economic growth using the post-financial-liberalization era data. With an Extended Constant Conditional Correlation GARCH model, it is shown that there are volatility spillovers from the capital inflows to growth in Turkey. Some earlier studies in literature have already established a positive relationship between the capital inflows and economic growth in Turkey. According to their results, as the mean value of capital inflows to Turkey increases, so does the conditional mean value of Turkish economic growth. This study is important for it shows that as the volatility of capital inflows to Turkey increases, so does the volatility of Turkish economic growth.
\end{abstract}

Address Correspondence:

e-ISSN 2549-0303 Eğitim Mahallesi, MÜ Göztepe Kampüsü, 34722 Kadıköy/İstanbul,

Turkey E-mail: orcun.soylemez@marmara.edu.tr 


\section{INTRODUCTION}

According to the standard economic thinking, freely moving capital across national borders should foster higher economic growth around the world for at least two reasons. First, the inflow of capital from abroad should provide the necessary funds for the high-return investments at the countries that would otherwise suffer from financing shortages. Second, the outflow of capital should allow for higher returns and better risk diversification for the investors in the countries that send capital abroad. ${ }^{1.1}$.

Clearly, this supposedly positive relationship between the free international capital flows and economic growth assumes a causality from the mean of capital flows to the conditional mean of growth since the formulation is simply as follows: more capital flows translate into higher growth rates around the world. This standard formulation is open to debate in two ways.

First, the positive relationship between the capital flows and growth has been called into question by a growing number of studies lately. Among them, Köse et al. (2006) have reported that capital inflows to the developing countries did not have statistically significant impact on the economic growth of these countries. ${ }^{1.2}$ More interestingly, Prasad et al. (2007) have found a statistically significant negative relationship between the capital inflows and growth. Prasad et al. have also argued that the positive relationship existed between the growth rates and capital outflows. ${ }^{1.3}$. Therefore, the first point open to debate is the existence of an unconditional positive correlation between capital inflows and growth as assumed by the standard thinking. In a recent paper, Söylemez and Y1lmaz (2013) have formally shown that capital inflows Granger cause growth in Turkey, which is a capital-attracting developing country.

Second, the international capital flows are notorious for being highly volatile. Therefore, a second point open to debate should be the possibility of volatility spillovers from the capital flows to growth. In their paper, using a near-VAR model which allowed for linear interdependencies between the growth and capital flows, Söylemez and Y1lmaz have also reported that almost half of the variation in Turkish economic growth could be explained by the shocks to the capital inflows to Turkey. Hence, according to their results, capital shocks linearly create significant levels of growth volatility in Turkey. In another paper, Söylemez and Demirci (2013) have shown with a nonparametric causality test that the causal relationship from capital inflows to growth in Turkey has nonlinear nature as well. Nonlinear causalities might happen due to nonlinear volatility interactions between capital inflows and growth. Furthermore, Söylemez and Demirci have also documented that growth is not a pull-factor for capital inflows, meaning that capital inflows to Turkey are totally exogenous.

This is an important topic because if one concentrates only on the mean value correlations between the capital inflows and growth, then he would be tempted to conclude capital inflows are beneficial to Turkey. However, such conclusion which only concentrates on the mean values would be missing an important part, i.e. the risk of financing internal growth with external factors.

\footnotetext{
1.1. Sumru Öz (2012). Türkiye'ye Yönelik Sermaye Akımları ve Ekonomik Büyüme. Ekonomik Araştırma Forumu Politika Notu, 12-04, p.1.

1.2. However, they argued for the other benefits capital flows might provide for the developing countries such as macroeconomic discipline and deeper financial markets.

1.3. This finding of Prasad et al. attracted much attention in the literature since it was contrary to the general beliefs of a great number of developing countries and policy makers. As well known, since the early 1980s, many developing countries lifted their controls on cross-border capital transactions hoping to embark on higher rates of growth by attracting more capital from abroad. See Gourinchas and Jeanne (2007), Alfaro et al. (2008), Devereux and Sutherland (2009), Sandri (2010), Aizenman (2011) for the recent studies trying to explain the findings of Prasad et al.
} 
Therefore, in this paper we focus on the nonlinear volatility transmissions from capital inflows to growth in Turkey to see if there are any.

In this paper, we adopt Dynamic Conditional Correlation Garch (DCC-Garch) model to estimate the possible volatility interactions. We compare the DCC-GARCH model to Constant Conditional Correlation GARCH model of Bollerslev (1990) using an Lagrange Multiplier (LM) test proposed by Nakatani and Terasvirta (2007). Finally, we find volatility spillovers in Turkish data from capital flows to economic growth.

The rest of the paper is organized as follows. Dataset is described in section two. The DCCGarch model and the testing methodology for the volatility spillovers are introduced in section three. Estimation results and test results are presented in section four. Section five concludes.

\section{Dataset Description}

This study uses the quarterly observations on the year-over-year changes in capital inflows to Turkey over GDP ratio (hereafter simply referred to as the capital inflows) and the year-over-year quarterly growth rates of Turkish GDP (hereafter simply referred to as the growth). The observations are for the time period of 1992:Q1 - 2012:Q2, that is the period through which Turkey had no crossborder capital controls. ${ }^{2.1}$

Capital inflows are measured as the sum of foreign direct investments (FDI), portfolio investments, other investments and net errors and omissions. FDI, portfolio and other investments, and net errors and omissions data come from the Central Bank of Republic of Turkey's statistical database. ${ }^{2.2}$ GDP data comes from the Turkish Statistical Institute database. Figure 1 provides a visual representation of the two series.

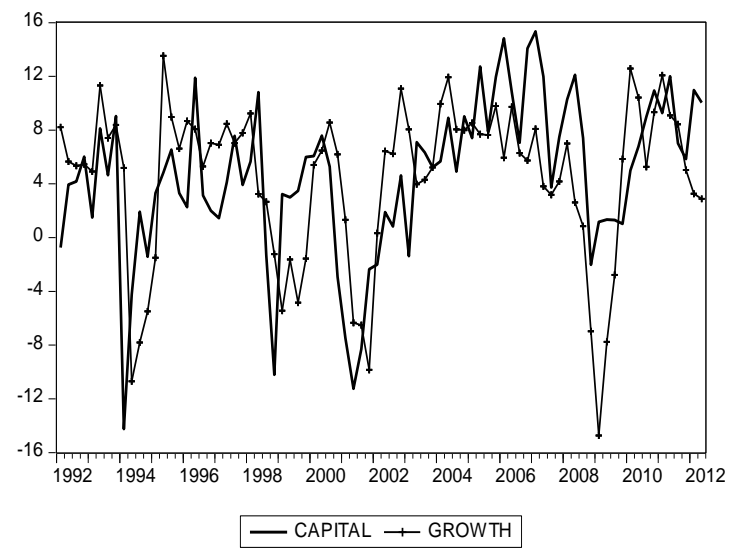

Figure 1. Growth and Capital Inflows in Turkey

Table 1 below summarizes the descriptive statistics of the two variables in this study (i.e. capital inflows and growth as described in the preceding paragraph). The two series have striking similatirity with respect to their means, standard deviations, and the values for the maximum and minimum observations, medians, skewness and kurtosis.

\footnotetext{
2.1. Turkey abolished all the controls on her capital account in August 1989 with the decree no:32.

2.2. The detailed quarterly figures for the year-over-year changes in capital inflows could be retrieved from the balance of payments dataset of the Central Bank of Turkey for the period beginning in 1992:Q1.
} 
Table 1. Descriptive Statistics of The Series

\begin{tabular}{|c|c|c|c|}
\hline & & Capital Inflows & Growth \\
\hline & Mean & 4.59 & 4.36 \\
\hline & Median & 5.12 & 5.90 \\
\hline & Maximum & 15.34 & 13.54 \\
\hline & Minimum & -14.24 & -14.74 \\
\hline & Std. Deviation & 5.81 & 5.92 \\
\hline & Skewness & -0.83 & -1.18 \\
\hline & Kurtosis & 4.04 & 3.84 \\
\hline & Coeff. of Variation & 1.27 & 1.36 \\
\hline & $05 \%$ Percentage & -8.17 & -7.80 \\
\hline 95 & $95 \%$ Percentage & 12.64 & 11.85 \\
\hline
\end{tabular}

\section{METHODOLOGY AND ESTIMATION RESULTS}

Since the introduction of ARCH model by Engle in 1982 and succesful generalization of it to GARCH model by Bollerslev in 1986, volatility modeling of financial time series has attracted substantial attention. The volatility concept has natural importance for risk management. However, more recent literature has began to use volatility to understand the degree and implications of financial integration as well. This line of research has adopted entended models of GARCH which help identify possible volatility spillovers between the financial time series. Numerous studies have found evidence for the fact that the conditional variances of financial time series interact, which is a signal of integration. Such empirical studies include Baillie and Bollerslev (1990), Cheung and $\mathrm{Ng}$ (1996), Hong (2001) among many others. Using such an extended GARCH model known as Extended Constant Conditional Correlation-GARCH model (ECCC-GARCH), we aim to study in this paper the possible volatility spillovers in the Turkish capital inflows and growth.

ECCC-GARCH model is first introduced by Jeantheau (1998) and nests the Constant Conditional Correlation-GARCH model of Bollerslev (1990). As Nakatani and Terasvirta describes, the ECCC-GARCH model allows the interaction in the form of both lagged squared innovations and lagged conditional variances from the other equations of the system while the CCC-GARCH model only allows contemporaneous dependence through conditional correlations. Therefore, the CCC-GARCH model cannot capture the whole volatility interaction through the variables in a system. ${ }^{3.1 .}$ The typical GARCH specification of Bollerslev (1986) is as follows.

$$
\varepsilon_{t}=z_{t} \sqrt{h_{t}}
$$

where, $\varepsilon_{t}$ denotes the error terms of a series modeled as GARCH process. Here $z_{t}$ is a whitenoise process centered around zero with a time-independent standard deviation. The second term, i.e. $\sqrt{h_{t}}$ denotes the time-dependent standard deviation or the conditional standard deviation of the errors. If the errors are following a GARCH(p,q) process, the conditional variance $h_{t}$ would be an $\operatorname{ARMA}(\mathrm{p}, \mathrm{q})$ process as follows.

$$
h_{t}=\alpha_{0}+\sum_{i=1}^{q} \alpha_{i} \varepsilon_{t-i}^{2}+\sum_{j=1}^{p} \beta_{j} h_{t-j}
$$

\footnotetext{
3.1. See Nakatani, T. and Terasvirta, T. (2007). Testing for Volatility Interactions in the Constant Conditional Correlation GARCH Model. Stockholm School of Economics SSE/EFI Working Paper Series in Economics and Finance, No. 649, p.2.
} 
The conditional variances $\left(h_{t}\right)$ of the ECCC-GARCH $(1,1)$ model for bivariate case would be then as follows.

$$
\begin{gathered}
h_{t}=\left[\begin{array}{l}
h_{1, t} \\
h_{2, t}
\end{array}\right]=a_{0}+A_{1}\left[\begin{array}{c}
\varepsilon_{1, t-1}^{2} \\
\varepsilon_{2, t-1}^{2}
\end{array}\right]+B_{1}\left[\begin{array}{l}
h_{1, t-1} \\
h_{2, t-1}
\end{array}\right] \\
=\left[\begin{array}{l}
a_{10} \\
a_{20}
\end{array}\right]+\left[\begin{array}{ll}
a_{11} & a_{12} \\
a_{21} & a_{22}
\end{array}\right]\left[\begin{array}{l}
\varepsilon_{1, t-1}^{2} \\
\varepsilon_{2, t-1}^{2}
\end{array}\right]+\left[\begin{array}{ll}
b_{11} & b_{12} \\
b_{21} & b_{22}
\end{array}\right]\left[\begin{array}{l}
h_{1, t-1} \\
h_{2, t-1}
\end{array}\right]
\end{gathered}
$$

The difference of the above notation from typical CCC-GARCH model is that $a_{12}, a_{21}, b_{12}$, and $b_{21}$ would be equal to zero in the typical GARCH specification. That is to say, in the typical GARCH case, the GARCH specification would be univariate and the lagged squared innovations and the lagged conditional variances from the other equations would not have any impact.

Based on this fact, Nakatani and Terasvirta have proposed an LM test where the null hypothesis is " $H_{0}: A_{1}$ and $B_{1}$ are diagonal matrices", while the alternative hypothesis is " $H_{a}:$ at least one of $A_{1}$ or $B_{1}$ is not diagonal". As shown by Nakatani and Terasvirta, the LM test statistic would have a chi-square distribution with relevant degrees of freedom. In our case, since we have a bivariate case (capital inflows and growth), our test statistic has a chi-square distribution with four degrees of freedom (because we impose four restrictions for the test, i.e. $H_{0}: a_{12}=a_{21}=b_{12}=b_{21}=$ $0)$.

To estimate the CCC-GARCH and ECCC-GARCH models and test to select one of them based on Nakatani and Terasvirta's LM test, we used the "ccgarch" package provided by Nakatani and Terasvirta for the open-access software R. We used the most widely used GARCH specification for the time series, i.e. GARCH $(1,1)$ model. ${ }^{3.2}$. The estimation outputs and test results are presented below.

Table 2. Estimation Results for the Bivariate CCC/ECCC-GARCH(1,1) Models of Capital Inflows

\begin{tabular}{|c|c|c|c|c|c|}
\hline Variable & $a_{0}$ & \multicolumn{2}{|c|}{$A_{1}$} & \multicolumn{2}{|c|}{$B_{1}$} \\
\hline \multicolumn{6}{|c|}{ CCC-GARCH } \\
\hline Capital Inflows & $\begin{array}{c}12.0194 \\
(0.98)\end{array}$ & $\begin{array}{c}0.4224 \\
(6.90)\end{array}$ & - & $\begin{array}{c}0.3791 \\
(4.25)\end{array}$ & - \\
\hline Growth & $\begin{array}{l}2.8959 \\
(12.16)\end{array}$ & - & $\begin{array}{l}3.4 \mathrm{E}-11 \\
(2.9 \mathrm{E}-13)\end{array}$ & - & $\begin{array}{c}0.9443 \\
(0.42)\end{array}$ \\
\hline \multicolumn{6}{|c|}{ ECCC-GARCH } \\
\hline Capital Inflows & $\begin{array}{c}2.1 \mathrm{E}-09 \\
(1.3 E-10)\end{array}$ & $\begin{array}{c}0.5152 \\
(7.31)\end{array}$ & $\begin{array}{c}0.1130 \\
(1.3 E-02)\end{array}$ & $\begin{array}{c}0.3752 \\
(5.35)\end{array}$ & $\begin{array}{l}3.6 \mathrm{E}-12 \\
(5.3 E-11)\end{array}$ \\
\hline Growth & $\begin{array}{c}8.4106 \\
(51.7)\end{array}$ & $\begin{array}{c}5.9 \mathrm{E}-11 \\
(6.36)\end{array}$ & $\begin{array}{l}2.6 \mathrm{E}-12 \\
(8.5 E-12)\end{array}$ & $\begin{array}{l}13.55 \\
(2.34)\end{array}$ & $\begin{array}{c}0.7345 \\
(4.39)\end{array}$ \\
\hline$\overline{\mathrm{LM}_{E C C C}}$ & & & & & \\
\hline
\end{tabular}
and Growth Series

The numbers in parentheses are the t-statistics while the number in square brackets is the $p$-value for $\mathrm{LM}_{E C C C}$ test statistics.

3.2. $\mathrm{GARCH}(1,1)$ is widely used because it is easy to compute and works pretty well with the real life data. See Bollerslev's lecture notes on world wide web at http://public.econ.duke.edu/ boller/Econ.350/talk_garch_11.pdf p.7. 
$\mathrm{LM}_{E C C C}$ in Table 2 is the test statistic for the test proposed by Nakatani and Terasvirta. The very small p-value associated with the $\mathrm{LM}_{E C C C}$ test statistic indicates that $A_{1}$ and $B_{1}$ are not diagonal matrices (i.e. there are volatility spillovers in the system and ECCC-GARCH $(1,1)$ model captures the whole volatility interactions better). The significance test results for the estimated coefficients indicate the direction of those volatility spillovers detected by the Nakatani-Terasvirta test. According to the significance test results of the estimated coefficients in the ECCC-GARCH $(1,1)$ model; $a_{20}, a_{11}, a_{21}, b_{11}, b_{21}, b_{22}$ are statistically significant. Significance of $a_{21}$ indicates that the squared innovation of capital inflows at time $t-1$ has positive influence on the volatility of growth at time $t$ and the significance of $b_{21}$ indicates that the lagged volatility of capital inflows has positive influence on the volatility of growth at time $t$. Since $a_{12}$ and $b_{12}$ are not significant, the lagged volatilities and squared innovations of growth do not have comparable influence on capital inflows. We also found that squared innovations of growth do not have influence on growth while lagged volatilities of growth do have. This is an interesting result because we evaluated it as the conditional volatility of growth at time $t-1$ is likely to continue creating volatility at time $t$, while a shock to Turkish economic growth is not prone to be persistent.

\section{CONCLUSIONS}

The standard economic thinking about the international capital flows and economic growth assumes a positive relationship between the capital flows and economic growth which can be summarized as increased capital flows foster economic growth. Hence, in this supposedly positive relationship, capital flows serve as an explanatory variable with significantly positive slopes. Therefore, according to the standard economic thinking, the increases in the mean value of capital inflows should generate an increase in the conditional mean value of growth.

A positive association as summarized above between the mean values of these two time series is open to debate for two reasons. First, a growing literature documents that the supposed positive impact of capital inflows on growth has no empirical confirmation. Nevertheless, Söylemez and Y1lmaz (2013) have found that capital inflows boost growth in Turkey as predicted by the standard view. That is why although it is impossible to argue that standard view holds universally, it could be said that it holds for Turkey.

Second, the association need not be only related to the first moments of the series (i.e. mean values). Capital flows and growth could have interactions in their higher moments as well. In fact, there exists a large literature showing that financial series usually have volatility interactions (See for example Baillie and Bollerslev (1990), Cheung and Ng (1996), Hong (2001) and Hong et. al (2006) among others). This second point has been investigated in this paper. More precisely, the study in this paper has focused on the possible volatility interactions between the capital inflows and economic growth in Turkey.

With an extended constant conditional correlation GARCH model we have detected volatility spillovers from capital inflows to growth in Turkey. This finding is important because it shows that the volatility of economic growth in Turkey increases as the volatility of capital inflows increase. A vast number of studies in the literature have already discussed that the volatility of capital flows could directly translate directly into greater financial market and real economic volatilities in capital attracting countries. In this regard, Agenor (2003) has argued that volatility in capital inflows tend to cause exchange rate instability under flexible exchange rates or large fluctuations in official reserves under a pegged exchange rate regime, and greater volatility in domestic equity markets. Agenor has further argued that financial volatility might also lead to adverse real effects. For example, nominal exchange rate volatility might hamper the exports in the 
absence of appropriate hedging techniques for domestic producers. Stiglitz (2000) has argued that as the volatility of capital flows increased, the possibility of recessions increased and that in return made the investments less attractive in the countries receiving highly volatile capital.

In conclusion, the existence of volatility spillovers from the capital inflows to economic growth - as evidenced for Turkey in this paper - could be a real problem for any capital-attracting country.

In the specific case of Turkey, for the sake of sustaining high growth with low volatility, Turkey must increase the proportion of less volatile modes of capital in its external financing mix such as foreign direct investments. According to The World Bank (1999), foreign direct investments are less volatile than, and therefore not as disruptive as, the short term capital inflows which can easily rush into a country and just as precipitously rush out. Unfortunately, foreigners' short term portfolio investments in Turkey have historically been the major form of international capital entering the country.

Secondly, the domestic saving rate in Turkey has declined substantially since the early 2000s and is now standing at alarmingly low levels. World Bank (2011) reports that "the domestic saving rate declined from an average of 23.5 percent of gross national income in the 1990s to an average of 17 percent over the 2000-2008 period, and further to 12.7 percent in 2010." Such declines in savings create significant savings-investments gap and make external financing a necessity. That is why, a high growth economy, Turkey is highly dependent on the international capital inflows in the first place. If Turkey can manage to increase the domestic savings, its dependence on international capital would decrease and so the close association between the capital inflows and growth (as evidenced by Figure 1 and Graph 1 in this paper) could be broken.

Thirdly, Turkey chronically runs current account (CA) deficits. International capital inflows are important for Turkey in squaring its CA deficits as well. One of the major reasons of Turkish CA deficits is the country's substantial energy imports bill. As the country representative office of The World Bank reports, almost 60 percent of Turkey's production relies on imported energy. To answer Turkey's growing power and energy needs without increasing the country's dependence on international capital, two measures could be taken. First, nearly 60 percent of Turkey's power currently comes from fossil fuels, almost all of which are imported. Turkey could begin benefiting from nuclear power, a carbon emission free energy source which Turkey has never used until now and increase its wind power extraction capacity since especially Turkey's western parts have stable and continuous wind streams throughout the year. Second, Turkey could increase its efficient use of energy as mentioned again by the country representative office of The World Bank.

Finally, according to the European Union, Turkey is the least innovative economy in Europe. As of 2011, Turkey had the sixth lowest labour productivity among the OECD members as measured in terms of GDP per hour worked. As stated in a recent Chatcam House report about Turkey, "Turkey is also ranked 90th out of 187 countries by UNDP in terms of average duration of education for 25-year-olds. In addition, the World Economic Forum ranked Turkey 63rd, 74th, and 124th out of 144 countries in terms of primary education and healthcare, higher education and training, and labour market efficiency." As these numbers indicate, low educational quality, low labour productivity, and low innovation capacity are the current restraints of Turkey on shifting to higher sophistication levels in exports. As a result, these restraints also remain as the major obstacles as Turkey attempts to contain its CA deficits. Therefore, Turkey's exports could increase (and in return the country's dependence on international capital could decrease) once the country achieves better educational qualities, higher labour productivity and an increase in its innovative capacity. 


\section{REFERENCES}

Agenor, P. (2003). "Benefits and Costs of International Financial Integration: Theory and Facts." The World Economy, 26 (8), pp. 1089-1118.

Aizenman, J., Jinjarak, Y. and Donghyun, P. (2011) "Capital Flows and Economic Growth in the Era of Financial Integration and Crisis 1990-2010.” NBER Working Paper, No. w17502.

Alfaro, L., Kalemli-Özcan, Ş. and Volosovych, V. (2008) "Why Doesn't Capital Flow from Rich to Poor Countries? An Empirical Investigation." The Review of Economics and Statistics, 90(2), pp. 347-68.

Baillie, R. T., and Bollerslev, T. (1990) "Intra-Day and Inter-Market Volatility in Foreign Exchange Rates." Review of Economic Studies, 58, pp. 565-585.

Bollerslev, T. (1990). "Modeling the Coherence in Short-Run Nominal Exchange Rates: A Multivariate Generalized ARCH Approach." Review of Economics and Statistics, 72, pp. 498-505.

Bollerslev, T. (2011, Spring). ARCH and GARCH Models. $<$ http://public.econ.duke.edu/ boller/Econ.350/talk_garch_11.pdf> (accessed January 02, 2017).

Bollerslev, T. (1986) "Generalized Autoregressive Conditional Heteroskedasticity." Journal of Econometrics, 31, pp. 307-327.

Cheung, Y.-W., and Ng, L. K. (1996). "A Causality-in-Variance Test and its Application to Financial Market Prices." Journal of Econometrics, 72, pp. 33-48.

Devereux, M. B. and Sutherland, A. (2009). "A Portfolio Model of Capital Flows to Emerging Markets." Journal of Development Economics, 89(2), pp. 181-93

Engle, Robert F. (1982). "Autoregressive Conditional Heteroscedasticity with Estimates of Variance of United Kingdom Inflation." Econometrica, 50, pp. 987-1008.

European Commission (Enterprise and Industry Directorate-General), Innovation Union Scoreboard 2011.

Ghosh, A., Kim, J., Qureshi, M. S. and Zalduendo, J. (2012). "Surges.” IMF Working Paper, 12/22.

Gourinchas, P-O. And Jeanne O. (2007). "Capital Flows to Developing Countries, The Allocation Puzzle." NBER Working Papers, 13602.

Hakura, F. (2013). "After the Boom: Risks to the Turkish Economy”. Chatham House Briefing Paper: Europe BP 2013/02.

Hong, Y. (2001). "A Test for Volatility Spillover with Application to Exchange Rates." Journal of Econometrics, 103, pp. 183-204.

Jeantheau, T. (1998). "Strong Consistency of Estimators for Multivariate ARCH Models." Econometric Theory, 14, pp. 70-86.

Köse, A., Prasad, E., Rogoff, K. and Wei S. J. (2006). "Financial Globalisation, A Reappraisal." International Monetary Fund Working Paper, 06/189.

Nakatani, T. and Terasvirta, T. (2007). "Testing for Volatility Interactions in the Constant Conditional Correlation GARCH Model." Stockholm School of Economics SSE/EFI Working Paper Series in Economics and Finance, No. 649.

Öz, S. (2012, June). “Türkiye’ye Yönelik Sermaye Akımları ve Ekonomik Büyüme.” Koç Üniversitesi Ekonomik Araştırma Forumu Politika Notu, 12-04.

Prasad, E., Rajan, R. and Subramanian, A. (2007). "The Paradox of Capital." Finance and Development, 44(1).

Söylemez, A. O, Demirci S. (2013). "The Nonlinear Causality Between the International Capital Flows and Economic Growth in Turkey." Finansal Araştırmalar ve Çalışmalar Dergisi, No. 8.

Söylemez, A. O., Yılmaz A. (2013). "Türkiye Ekonomisinde Finansal Serbestleşme Döneminde Uluslararası Sermaye Girişi - Büyüme İlişkisi.” T.C. Marmara Üniversitesi İktisadi ve İdari Bilimler Dergisi, 2013, No. 1.

Stiglitz, J. (2000). "Capital Market Liberalization, Economic Growth, and Instability." World Development, 28 (6), pp. 1075-1086

The World Bank, Country Economic Memorandum 2011. Sustaining High Growth: The Role of Domestic Savings. Turkey Country Economic Memorandum Report No. 66301-TR.

UNDP, Human Development Report 2012.

World Economic Forum, Global Competitiveness Report 2012-2013. 